\title{
ANALYSIS OF THE HEART RATE VARIABILITY FOR WOMEN, SPECIALIZING IN RACE WALKING, THROUGHOUT THE MENSTRUAL CYCLE
}

\author{
Svitlana Kalytka, Nadia Borovska, Olha Roda, Maryna Karabuza
}

\author{
Lesya Ukrainka East European National University, Lutsk
}

Kalytka S., Borovska N., Roda O., Karabuza M. (2015), Analysis of the heart rate variability for women, specializing in race walking, throughout the menstrual cycle. Health Problems of Civilization, 4 (9), p. 5-10.

Summary: The article presents the results of studies of the heart rate variability for women, specializing in race walking, at different phases of the menstrual cycle (MC). The results of spectral analysis of heart rate indicate that the first half of the MC is dominated by the contribution of MC HF component, and the second half is dominated by the contribution of the LF component and an ovulatory phase is dominated by the contribution of VLF component in the total power spectrum. According to the results of the geometric analysis, the increase of Mo in menstrual and postmenstrual phases of the MC, reduction of AMo - in postmenstrual, ovulatory phases indicates an increase in the HR functional state in these phases. Decrease of the HR functional state we noted in the premenstrual phase: Mo rates have dropped, and AMo - increased. IT indicators of regulatory systems have increased in postovulatory and premenstrual phases of the MC. In this regard, we have recommended the use of significant and strenuous exercise with the consideration of female athletes' HR functional state in different phases of the MC.

Keywords: heart rate variability, spectral analysis, athletes, menstrual cycle, exercise, race walking

\section{Introduction}

Evaluation of the body's functional state and its adaptation reserves is one of the major problems, related to the solution of the most important tasks of athlete's training. High level of functional state should be considered as a premise for a high physical efficiency, as the potential ability to effectively adapt to the required competitive and training load. In its turn, adaptation to physical stress can act as one of the important characteristics of the functional state (Banzer et al. 2006, Shlyk, Sapozhnikova 2010).

The cardiovascular system (CVS), being the most important element, which limits the development of adaptive reactions of the body, simultaneously can serve as an indicator of adaptive reactions in response to physical stress. Information on the functional state of the body can be obtained by studying the mechanisms of heart rate regulation. Heart rate parameters' change reflects the adaptation capabilities of the body's regulatory systems and the dynamics of their development (Bayevskiy et al. 2001, Bayevskiy 2004, Report of the Working Group of the European Society of Cardiology and the North American Society of Cardiostimulation and Electrophysiology 1999).

Currently there are many studies of athletes' heart rate variability (HRV). Regulatory systems' state and their ability to provide the necessary adaptation to the physical loads are crucial in the prediction of fitness (Kovalenko 2006, Karpman et al. 1974, Kotelnikov et al. 2002).

Many studies have shown that the achievement of high results is inextricably linked to the effectiveness of the athletes' training process, herewith, one of the most important principles is the accordance of loads to the functional status at a given time, that is, the combination of exercise and rest periods for an athlete.

It is known, that one of the objective criteria of the current functional status and physical fitness of athletes' evaluation is physiological indicators, which reflect the mechanisms of sympathetic and parasympathetic nervous systems, in other words, autonomic cardiovascular regulation. Properly balanced regulation allows the athlete with a proper level of motivation to maximize his functionality and provides the necessary economization of functions while working on endurance and determines the recovery phase (Apanasenko 2002, Karpman et al. 1974, Shakhlina 2001).

Address for correspondence: Svitlana Kalytka, East European National University named after Lesya Ukrainka, Voli Ave, 13, Lutsk, Volyns'ka oblast, Ukraina, e-mail: sv-kalitka@ukr.net, phone: +38 0955547719

Tables: 1 Figures: 1 References: 11 Full-text PDF www.hpc.edu.pl Copyright (C Pope John Paul II State School of Higher Education in Biała Podlaska, Sidorska 95/97, 21-500 Biała Podlaska Indexation: Index Copernicus, AGRO, ProQuest, Polish Medical Bibliography, Polish Ministry of Science and Higher Education. This is an open-access article distributed under the terms of the Creative Common Attribution Non-commercial license (http://creativecommons.org/licenses/by-nc/3.0), which permits use, distribution and reproduction in any medium, provided the original works is properly cited, the use is non-commercial and is otherwise in compliance with the license. 
As a rule, the violation of HR vegetative regulation is an early sign of the body's failure to adapt to physical loads and leads to a decrease in efficiency. In recentyears, to evaluate the functional status of athletes is becoming more popular analysis of HRV, or cardiointervalography, which is a simple, non-invasive and informative method of the autonomic nervous system studying.

HRV is an integral indicator of the HR functional state and the body in general. Low HRV indexes, observed within the vegetative nervous system sympathetic section domination, indicate a lack of recovery of athletes after strenuous physical exercise, overtraining, intoxication and other pathological conditions (Bayevskiy 2004, Mikhaylov 2000, Kotelnikov et al. 2002).

Currently, there is a number of methods of HRV analysis. Among them there are methods of temporary analysis, variation heart rate monitor, frequency analysis methods.

Temporal and spectral HRV analysis provides the most valuable information on the athletes' functional status in a particular period of time, and depending on their level of opportunely adjustments to the training process. It follows, that the use of the heart rate variability temporal and spectral analysis in practice of high-level athletes' training is necessary and promising (Bayevskiy 2004, Mikhaylov 2000).

It is known, that adaptation processes for women differ from those for men. This is due to one of the main biological characteristics of the female body, associated with reproduction - cycles of the hypothalamicpituitary-ovarian-adrenal system. Many authors have described changes in the general and special efficiency, in functional possibilities; of female athletes' recovery after the load in different phases of the menstrual cycle (MC). Survey results of the dependence of the functional possibilities display and the effectiveness of the specific loads execution from the state of the female athletes' body in different phases of the MP became a methodological basis of the training programs' development and competitive activities during mezocycles (Apanasenko 2002, Shakhlina 2001).

In race walking, in the adaptation to high physical activity of high intensity and duration (in case of oxygen deficiency), the most vulnerable is HR, which often leads to overtraining and the disruption of adaptation. Therefore, in women training, particular importance should be paid to control of the HR functional state in different phases of the MC, for a deeper study of the body's adaptive processes to great training and competitive loads.

\section{The aim of our study}

The aim of our study was to examine the features of HRV for women athletes, specializing in race walking, in different phases of the MP.

\section{Research methods}

A total of 6 women was examined (36 cases), specializing in race walking at the age of 17 to 28 years from the day 28-32 MC, having the qualification of first level, candidate to the master of sports, masters of sports and masters of sports of international class. Researches were carried out in each phase of the MC, namely: I phase menstrual (1-5 day of the MC), II phase - postmenstrual (6-12 day of the MC), III phase - ovulatory (13-15 day of the MC), IV Phase - postovulatory (16-25 of the MC) and V phase - premenstrual (26-28 day of the MC). For the study of the hormonal saturation the concentration of oestradiol and progesterone in serum was determined.

An analysis of HRV indexes by writing down the ECG of skilled athletes, who have taken a survey with the use of software-hardware complex "Poly-Spectrum" in 2009 - 2011 years, was held. Artifacts and extra systoles were removed from the electronic record with the automatic and manual methods.

The following time indexes of heart rate variability were analyzed: heart rate, RRNN (average duration of normal intervals RR), SDNN (standard deviation of NN-interval values, square root of the spread NN), RMSSD (square root mean square difference between adjacent RR-intervals), pNN50 (percentage of intervals adjacent $\mathrm{NN}$, differing by more than $50 \mathrm{~ms}$ ), CV (coefficient of a series of successive cardio intervals variation RR-, SDNN / RRNN • 100\%).

Among the indicators of spectral (frequency) analysis the total power of the spectrum, high-frequency power (HF), low frequency (LF) and very low frequency (VLF) components, the contribution of these components to the total power spectrum as a percentage, as well as the power of HF-and LF-waves, normalized units and the ratio of $\mathrm{LF} / \mathrm{HF}$ were evaluated.

We used the following parameters of the Cardiointervalography (CIG): Mo (mode - the most frequently occurring values of RR-interval), AMo (mode amplitude - the percentage of RR-RR, corresponding to the value of mode), VR (variation range - the difference between the length of the maximum and minimum RR-interval) and 
calculated on their basis indices, proposed by R.M. Bayevskiy (2001) and widely used to evaluate the processes of regulation and the degree of adaptation of the cardiovascular system to aggressive factors: IVG - Index of vegetative balance (IVG = AMo / VR); IAVB - an indicator of the adequacy of regulatory processes (IAVB = AMo / Mo) VIR - vegetative index rate (VIR $=1 /$ Mo $\bullet$ VR) IT - index tension of regulatory systems (ID = AMo $/ 2 \bullet \mathrm{VR}$ - Mo). All survey parameters were studied at the state of rest (background sample), the day before the study female athletes were released from training. Statistical analysis was performed, using Statistica 6.0 program.

\section{Results and the dispute}

Increase of the strenuous physical exercise use efficiency in combination with other exogenous and endogenous influences is one of the most important problems of modern sport. It is known, that endogenous hormonal changes, which occur during the MC, affect mood, functionality, affectivity, and, consequently, athletic performance. Taking into consideration, that in the first half of the MC parasympathetic tone of the nervous system is dominating and in the second half the sympathetic tone of regulation is increasing, the data of the autonomic nervous system tone changes should affect the mechanisms of the female athletes' heart rate regulation.

Our studies of the HF, LF and VLF components' contribution into the total power of female athletes' HR fluctuations in different phases of the MC showed, that during menstrual and postmenstrual phases prevalence of HF component $(48,16 \pm 8,28 \%$ and $48,90 \pm 9,90 \%$ match) is observed (Fig. 1).

In ovulatory, postovulatory and premenstrual phases of the MC the influence of HF component was significantly reduced $(\mathrm{p}<0,05)(36,40 \pm 9,75 \%, 43,88 \pm 8,95 \%$ and $39,63 \pm 13,90$, respectively) and the contribution of LF and VLF components in the total power of female athletes' HR fluctuations is increasing. Contribution of the LF component was significantly higher $(\mathrm{p}<0.05)$ in the premenstrual phase of the MC $(26,73 \pm 7,03 \%)$, compared with the menstrual and ovulatory phases $(20,18 \pm 3,85 \%$ and $19,97 \pm 3,97 \%$, respectively), while the contribution of VLF component was significantly higher $(\mathrm{p}<0.05)$ in ovulatory phase $(43,60 \pm 13,30 \%)$, compared with the menstrual, postmenstrual, postovulatory and premenstrual phases $(31,64 \pm 8,86 \%, 26,97 \pm 8,82 \%, 33,84 \pm$ $1,34 \%$ and $33,62 \pm 9,13 \%$, respectively).

I

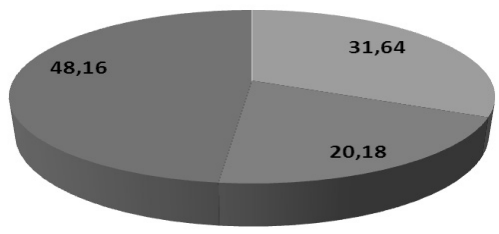

III

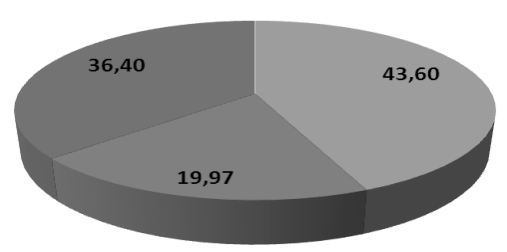

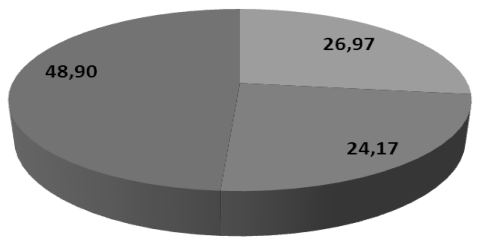

IV

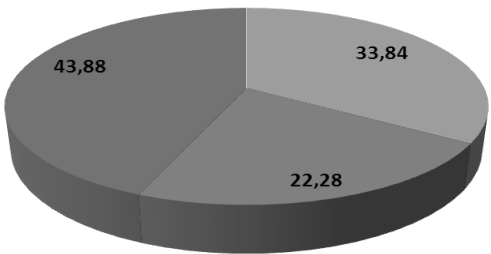

v

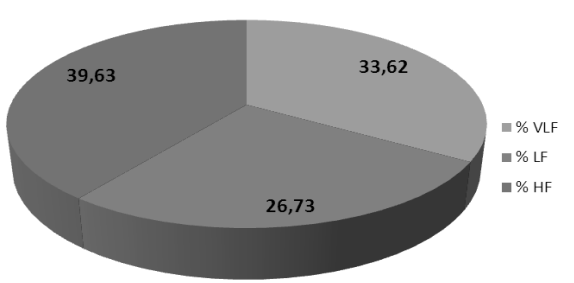

Figure 1. Change in the contribution (\%) of high-frequency (HF), low frequency (LF) and very low frequency (VLF) components into the total power of the female athletes' heart rate fluctuations in different phases of the MC (I phase menstrual, II phase - postmenstrual, III phase - ovulatory, IV phase - postovulatory and V phase - premenstrual) 
Taking into consideration, that the race walking is a cyclical sport, developing mainly aerobic endurance, for the female athletes, due to the structural trail of long-term adaptation to the physical activities, regulatory influence of the straying nerve on the heart may be noticed. We have marked a remarkable predominance of HR component contribution during the MC, which confirms the predominance of parasympathetic tone of the nervous system, especially in the first half of the MC.

A decrease in the level of sympathetic ANS mobilization in response to the use of regular physical activity may be the cause of the poor expression of the contribution of LF component to the total power of female athletes' heart rate fluctuations in different phases of the MC. Such changes in the influence of the sympathetic and parasympathetic divisions of the SNC, which are displayed in the balance of LF / HF, suggest, that these rates are increasing during the $\mathrm{MC}$ and in the menstrual phase, they are $0,45 \pm 0,11$, in postmenstrual $-0,57 \pm 0,17$, in the ovulatory $-0,59 \pm 0,08$, in postovulatory $-0,62 \pm 0,29$ and premenstrual $-0,93 \pm 0,46$ (table 1 ). The predominance of the HF component contribution, especially in the first half of the MC, significantly influences the female athletes' heart rate $(\mathrm{HR})$ and we have highlighted significantly lower $(\mathrm{p}<0.05)$ indicators in the menstrual $(58,50 \pm 4,53$ beats $\left.\cdot \min ^{-1}\right)$ and postmenstrual $\left(54,00 \pm 7,00\right.$ beats $\left.\cdot \mathrm{min}^{-1}\right)$ phases, compared with ovulatory $(66,00 \pm 6,50$ beats $\left.\bullet \mathrm{min}^{-1}\right)$, postovulatory $\left(66,20 \pm 2,87\right.$ beats $\left.\bullet \mathrm{min}^{-1}\right)$ and premenstrual $\left(65,67 \pm 7,43\right.$ beats $\left.\bullet \mathrm{min}^{-1}\right)$.

As the results of our study have shown, a significant increase in the contribution of VLF component into the total power spectrum of female athletes' heart rate in the second half of the MC, especially in the phase of ovulation $(43,60 \pm 13,30 \%)$, may indicate high concentrations of estrogen and progesterone in the blood. Considering the fact, that in the second half of the MC there is a sharp change in the correlation between the concentration levels of estrogen and progesterone, then such an impact on the structure of the sinus node can affect the RR intervals due to the changes in myocardial metabolism. It follows, that the prevalence of VLF component contribution to the total spectral power of the female athletes' heart rate may indicate a change in the secretor activity of the female gonad in certain phases of the MC.

Table 1. HR variability indexes for female athletes' in different phases of the MC

\begin{tabular}{|c|c|c|c|c|c|}
\hline \multirow{2}{*}{ Parameters } & \multicolumn{5}{|c|}{ Phases MC } \\
\hline & I & II & III & IV & $\mathbf{V}$ \\
\hline $\mathrm{TP}, \mathrm{ms}^{2}$ & $\begin{array}{c}3628,20 \pm \\
1096,80\end{array}$ & $\begin{array}{c}2657,33 \pm \\
208,17\end{array}$ & $\begin{array}{c}2926,33 \pm \\
769,67\end{array}$ & $\begin{array}{c}2434,20 \pm \\
1047,53\end{array}$ & $\begin{array}{c}1905,83 \pm \\
975,24\end{array}$ \\
\hline VLF, $\mathrm{ms}^{2}$ & $\begin{array}{c}1077,80 \pm \\
361,13\end{array}$ & $\begin{array}{c}711,00 \pm \\
249,00\end{array}$ & $\begin{array}{c}1292,67 \pm \\
659,67\end{array}$ & $\begin{array}{c}818,20 \pm \\
333,87\end{array}$ & $\begin{array}{c}524,00 \pm \\
178,86\end{array}$ \\
\hline $\mathrm{LF}, \mathrm{ms}^{2}$ & $751,00 \pm 294,67$ & $633,67 \pm 39,17$ & $589,67 \pm 217,67$ & $547,40 \pm 320,07$ & $436,83 \pm 193,24$ \\
\hline $\mathrm{HF}, \mathrm{ms}^{2}$ & $\begin{array}{c}1799,40 \pm \\
683,07\end{array}$ & $\begin{array}{c}1313,33 \pm \\
338,33\end{array}$ & $\begin{array}{c}1044,67 \pm \\
460,67\end{array}$ & $\begin{array}{c}1069,00 \pm \\
515,33\end{array}$ & $945,33 \pm 726,95$ \\
\hline LF norm, n.u. & $30,22 \pm 5,14$ & $34,77 \pm 6,32$ & $36,87 \pm 3,12$ & $26,21 \pm 12,99$ & $42,75 \pm 13,61$ \\
\hline HF norm, n.u. & $69,78 \pm 5,41$ & $65,23 \pm 6,32$ & $63,13 \pm 3,12$ & $65,80 \pm 12,13$ & $57,25 \pm 13,61$ \\
\hline $\mathrm{LF} / \mathrm{HF}$ & $0,45 \pm 0,011$ & $0,57 \pm 0,17$ & $0,59 \pm 0,08$ & $0,62 \pm 0,29$ & $0,93 \pm 0,46$ \\
\hline $\mathrm{R}-\mathrm{R} \min , \mathrm{ms}$ & $890,00 \pm 68,67$ & $1020,00 \pm 123,50$ & $795,67 \pm 93,17$ & $804,20 \pm 25,80$ & $834,83 \pm 100,67$ \\
\hline $\mathrm{R}-\mathrm{R} \max , \mathrm{ms}$ & $1196,40 \pm 104,4$ & $1282,00 \pm 141,00$ & $1052,00 \pm 108,0$ & $1018,00 \pm 60,00$ & $1039,83 \pm 119,86$ \\
\hline RRNN, msc & $1040,40 \pm 92,87$ & $1148,00 \pm 132,50$ & $929,00 \pm 100,00$ & $908,00 \pm 37,67$ & $936,00 \pm 112,00$ \\
\hline SDNN, ms & $62,40 \pm 10,60$ & $56,67 \pm 3,83$ & $55,00 \pm 10,00$ & $48,20 \pm 10,20$ & $41,83 \pm 12,95$ \\
\hline RMSSD, ms & $73,20 \pm 12,47$ & $72,33 \pm 10,83$ & $58,00 \pm 14,50$ & $55,60 \pm 13,40$ & $47,67 \pm 23,90$ \\
\hline pNN50, \% & $46,60 \pm 12,97$ & $54,43 \pm 6,03$ & $35,83 \pm 12,88$ & $39,47 \pm 15,30$ & $27,35 \pm 21,63$ \\
\hline $\mathrm{CV}, \%$ & $5,97 \pm 0,78$ & $4,99 \pm 0,26$ & $5,93 \pm 0,85$ & $5,24 \pm 0,90$ & $4,43 \pm 0,94$ \\
\hline HR, beats $\bullet \mathrm{min}^{-1}$ & $59,00 \pm 4,33$ & $54,00 \pm 7,00$ & $66,00 \pm 6,50$ & $66,40 \pm 2,73$ & $65,67 \pm 7,43$ \\
\hline $\mathrm{M}, \mathrm{s}$ & $1,04 \pm 0,09$ & $1,15 \pm 0,13$ & $0,93 \pm 0,10$ & $0,91 \pm 0,04$ & $0,94 \pm-0,11$ \\
\hline $\mathrm{CK}, \mathrm{s}^{2}$ & $0,06 \pm 0,01$ & $0,06 \pm 0,001$ & $0,05 \pm 0,01$ & $0,05 \pm 0,01$ & $0,04 \pm 0,01$ \\
\hline Mo, s & $1,04 \pm 0,09$ & $1,15 \pm 0,12$ & $0,94 \pm 0,11$ & $0,89 \pm 0,03$ & $0,94 \pm 0,11$ \\
\hline AMo, $\%$ & $37,06 \pm 9,26$ & $31,00 \pm 1,80$ & $33,20 \pm 5,50$ & $37,70 \pm 7,47$ & $48,67 \pm 12,27$ \\
\hline $\mathrm{Me}, \mathrm{s}$ & $1,03 \pm 0,09$ & $1,14 \pm 0,13$ & $0,93 \pm 0,10$ & $0,90 \pm 0,04$ & $0,92 \pm 0,12$ \\
\hline VR, s & $0,31 \pm 0,05$ & $0,26 \pm 0,02$ & $0,23 \pm 0,04$ & $0,21 \pm 0,04$ & $0,20 \pm 0,04$ \\
\hline IVG, n.u.. & $137,12 \pm 55,92$ & $120,33 \pm 15,83$ & $169,30 \pm 66,35$ & $208,78 \pm 82,81$ & $288,48 \pm 103,73$ \\
\hline IAVB, n.u. & $36,56 \pm 11,03$ & $28,20 \pm 5,15$ & $37,17 \pm 8,92$ & $43,02 \pm 9,49$ & $54,10 \pm 16,03$ \\
\hline VIR, n.u. & $3,52 \pm 0,88$ & $3,53 \pm 0,69$ & $5,38 \pm 1,58$ & $5,88 \pm 1,35$ & $6,08 \pm 1,33$ \\
\hline IT, n.u. & $69,32 \pm 31,55$ & $55,83 \pm 14,48$ & $98,07 \pm 44,97$ & $120,66 \pm 50,23$ & $160,62 \pm 61,87$ \\
\hline
\end{tabular}


According to many authors, who conducted the research in the field of sports cardiology, decrease in heart rate, increase of Mo and decrease of AMo may serve to improve the functional state of the HR. Thus, we observed an increase of Mo in the menstrual $(1,04 \pm 0,09 \mathrm{~s})$ and postmenstrual $(1,15 \pm 0.12)$ phase, reduction of AMo in postmenstrual $(31,00 \pm 1,80 \%)$ and ovulatory $(33,20 \pm 5,50 \%)$ phases, which indicates an increase in the functional state of the HR during these phases. The decrease of the HR functional state was registered in the premenstrual phase: Mo rates dropped $-0,94 \pm 0,011 \mathrm{~s}$, and AMo increased $-48,67 \pm 12,27 \%$.

Increase in IT points to the tension of regulatory mechanisms and the increasing sympathetic channel regulation activity and parasympathetic and humoral ANS channels activity reducing. We found, that the lowest IT for female athletes were during menstrual $(69,32 \pm 31,55 \mathrm{cu})$, postmenstrual $(55,83 \pm 14,48 \mathrm{cu})$ and ovulatory $(98,07 \pm 44,97 \mathrm{cu})$ phases, which indicates the reduction of cardio regulation voltage, compared to postovulatory $(120,66 \pm 50,23 \mathrm{cu})$ and premenstrual $(160,62 \pm 61,87 \mathrm{cu})$ phases.

Therefore, an increase in IT, reduction in the contribution of the HF component, increase in the contribution of LF and VLF components in the premenstrual phase of the MC, identified by us, point out to an increase in sympathetic and humoral regulation of the heart rhythm against the background of weak estrogenic saturation of female athletes' blood.

\section{Findings}

1. Our studies of the spectral analysis of the female athletes' HR in different phases of the MC showed, that the total power spectrum in the menstrual and postmenstrual phase the prevalence of HF component is observed $(48,16 \pm 8,28 \%$ and $48,90 \pm 9,90 \%$ respectively). In ovulatory, postovulatory and premenstrual phases of the MC influence of the HF component was significantly reduced $(p<0,05)(36,40 \pm 9,75 \%, 43,88$ $\pm 8,95 \%$ and $39,63 \pm 13,90$, respectively) and increased the contribution of LF and VLF components in the total power of the female athletes' HR fluctuations. Contribution of the LF component was significantly higher $(\mathrm{p}<0.05)$ in the premenstrual phase of the MC $(26,73 \pm 7,03 \%)$, compared with the menstrual and ovulatory phases $(20,18 \pm 3,85 \%$ and $19,97 \pm 3,97 \%$, respectively), while the contribution of VLF component was significantly higher $(\mathrm{p}<0.05)$ in ovulatory phase $(43,60 \pm 13,30 \%)$, compared with the menstrual, postmenstrual, postovulatory and premenstrual phases $(31,64 \pm 8,86 \%, 26,97 \pm 8,82 \%, 33,84 \pm 1,34 \%$ and $33,62 \pm 9,13 \%$, respectively).

2. Stated the increase of Mo in menstrual $(1,04 \pm 0,09 \mathrm{c})$ and postmenstrual $(1,15 \pm 0.12 \mathrm{~s})$ phases of the $\mathrm{MC}$, reduction of AMo - in postmenstrual $(31,00 \pm 1,80 \%)$ and ovulatory $(33,20 \pm 5.50 \%)$ phases, which indicates an increase in the functional state of the HR in these phases. The decrease of the HR functional state we noted in the premenstrual phase: Mo rates dropped - 0,94 $\pm 0,011 \mathrm{~s}$, and AMo rates increased $48,67 \pm 12,27 \%$.

3. We found, that the lowest IT for female athletes were during menstrual $(69,32 \pm 31,55 \mathrm{cu})$, postmenstrual $(55,83 \pm 14,48 \mathrm{cu})$ and ovulatory $(98,07 \pm 44,97 \mathrm{cu})$ phases, which indicates the reduction of cardio regulation voltage, compared to postovulatory $(120,66 \pm 50,23 \mathrm{cu})$ and premenstrual $(160,62 \pm 61,87 \mathrm{cu})$ phases.

4. The results of changes in the functional state of female athletes' HR, specializing in race walking, during the MC may be used to plan the application of large and significant physical exercises in mezocycle and to improve the training process.

\section{References:}

1. Апанасенко Г.Л. (2002), Диагностика индивидуального здоровья. Валеология, по. 3, 27-31.

2. Баевский Р.М. (2004), Анализ вариабельности сердечного ритма: история и философия, теория и практика. Клиническая информатика и телемедицина, no. 1, 54-64.

3. Баевский Р.М., Иванов Г.Г. (2001), Вариабельность сердечного ритма: теоретические аспекты и возможности клинического применения. Ультразвуковая и функциональная диагностика, no. 3, 106-127.

4. Вариабельность сердечного ритма: стандарты измерения, интерпретации, клинического использования:ДокладРабочейгруппыЕвропейскогообществакардиологиии еевероамериканского общества кардиостимуляции и электрофизиологии //Вестник аритмологии. 1999, №. 11., С. 53-78.

5. Шахлина Л. Я.-Г. (2001), Медико-биологические основы спортивной тренировки женщин. Шахлина Л. Я.-Г. - К.: Наукова думка, 326.

6. Шлык Н.И., Сапожникова Е.Н. (2010), Ритм сердца и тип вегетативной регуляции у спортсменок в беге на средние дистанции в тренировочном процессе. Физкультура в профилактике, лечении и реабилитации, № 3-4 (34-35), 17-23. 
7. Исследование физической работоспособности у спортсменов /В. Л. Карпман, З. Б. Белоцерковский, И. А. Гудков -М.: ФиС, 1974.- 96 с.

8. Коваленко С.О. (2006), Індивідуальні особливості хвильової структури серцевого ритму при дозованому фізичному навантаженні. Спортивна медицин, по. 1, 3-9.

9. Котельников С.А., Ноздрачев А.Д., Одинак М.М. и др. (2002), Вариабельность ритма сердца: представления о механизмах. Физиология человека, Т. 28, no. 1, 130-143.

10. Михайлов В.М. (2000), Вариабельность ритма сердиа. Опыт практического применения. Иваново, 119.

11. W. Banzer, K. Lucki, M. Burklein et al. (2006), Sports medical aspects in cardiac risk stratification - heart rate variability and exercise capacity. Herzschrittmacherther Electrophysiol, no. 17(4), 197-204.

Submitted: 02.03.2014

Accepted: 10.06.2015 